\title{
Harvested Rainwater Quality: A Case Study Of Aule In Akure, South Western Nigeria
}

\author{
Ochuko Mary Ojo \\ Department of Civil and Environmental Engineering, \\ the Federal University of Technology, Akure, Nigeria
}

doi: 10.19044/esj.2016.v12n11p451 URL:http://dx.doi.org/10.19044/esj.2016.v12n11p451

\begin{abstract}
The quality of harvested rainwater in Aule area of Akure, South western Nigeria was assessed in this study. Water samples were collected from 25 rain water storage tanks within the study area and a well was used as a control. The water samples were subjected to detailed laboratory analysis and the results obtained was compared with World Health Organization (WHO) standard for drinking water. The turbidity values ranged from 2.7 to 9.1 NTU for the harvested rainwater samples while the well water sample had a turbidity of 2.3 NTU. The conductivity values for the rainwater samples ranged from 101 to $1328 \mathbf{\Omega s} / \mathbf{c m}$. The conductivity value was lower in the well water $(164 \mathbf{\Omega s} / \mathbf{c m})$ than in most of the harvested rain water samples. The $\mathrm{pH}$ of the harvested rainwater ranged from 6.1 to 7.4 with $36 \%$ of the water samples having a $\mathrm{pH}$ less than the WHO minimum limit of 6.5. The $\mathrm{pH}$ of the well water sample was 7.4 and was within the WHO acceptable limits of 6.5 to 8.5. All the sampled rainwaters and well water had bacteria in them. The total bacterial content of the rain water samples ranged from 05 to $28 \mathrm{CFU} / 100 \mathrm{~mL}$, while that of the well was $05 \mathrm{CFU} / 100 \mathrm{~mL}$. The total coliform contents of the rainwater samples ranged from 03 to 18 CFU/100 mL, while that of the well was $02 \mathrm{CFU} / 100 \mathrm{~mL}$. Based on the results obtained from this study, it is recommended that harvested rainwater be treated to kill contaminating microorganisms and to reduce the health risks associated with its consumption.
\end{abstract}

Keywords: Akure, harvested rainwater, storage tanks, consumption

\section{Introduction}

Water is identified as one of the most important natural resources because it is viewed as a key to prosperity and wealth (Arbués et al., 2003). Increase in human population has exerted an enormous pressure on the provision of safe drinking water especially in developing countries (Umeh et 
al., 2005). Freshwater quality and availability remain one of the most critical environmental and sustainability issues of the twenty-first century (UNEP, 2002). Unsafe water is a global public health threat, placing persons at risk for a host of diarrheal and other diseases as well as chemical intoxication (Hughes and Koplan, 2005). Unsanitary water particularly has devastating effects on young children in the developing world. Each year, more than 2 million persons, mostly children less than 5 years of age, die of diarrheal disease (Kosek et al., 2003; Parashar et al., 2003). Nearly 90\% of diarrhealrelated deaths have been attributed to unsafe or inadequate water supplies and sanitation conditions affecting a large part of the world's population (WHO, 2004; Hughes and Koplan, 2005). An estimated 1.1 billion persons (one sixth of the world's population) lack access to clean water and 2.6 billion to adequate sanitation (WHO, 2005; Hughes and Koplan, 2005). The sources of water supply in most parts of developing countries areas include conventional communal sources and self-supply sources.

Conformation of potable water with water quality standards is of special interest because of the capacity of water to spread diseases within a large population. Although the standards vary from place to place, the objective anywhere is to reduce the possibility of spreading water-borne disease in addition to being pleasant to drink, which implies that it must be wholesome and palatable in all respects (Edema et al., 2001; Okonko et al., 2008). A collaborative, interdisciplinary effort to ensure global access to safe water, basic sanitation, and improved hygiene is the foundation for ending cycle of poverty and diseases (Hughes and Koplan, 2005).

Well water is the main source of water in Akure, Ondo state as surface water is not reachable in most communities. However, well water is not easily accessible in some areas of Akure due to the rocky nature of the soil. The prospects of drilling bore hole for some residents of such areas is a mission that seems impossible to achieve. As a result, they result to rainwater harvesting to meet some of their water needs especially during seasons of high rainfall. . In the past, it was believed that rainwater was pure and could be consumed without pre-treatment. While this may be true in some areas that are relatively unpolluted, rainwater collected in many locations contains impurities. In the last three decades, “acid rain” has affected the quality of the collected water, to the point where it now usually requires treatment. Good quality drinking water should be free from disease-causing organisms and harmful chemical. Common health concerns for rainwater quality in developing countries are related to bacteria, particularly $e$-coli and to aesthetic properties, such as colour, taste, smell and hardness (Zhu, 2004). The aim of this study is to assess the quality of harvested rainwater in Aule area of Akure. 


\section{Methodology}

The study was carried out in Aule in Akure. Akure is the capital of Ondo state, which is located in the South-western part of Nigeria. Akure lies on latitude $7^{\circ} 15^{\prime}$ North of the Equator and on longitude $5^{\circ} 15^{\prime}$ east of the Greenwich meridian. Water samples were collected from 25 rain water storage tanks within the study area. A sample was also collected from a well to serve as control. Plate 1 shows a typical rain water harvesting system in the study area.

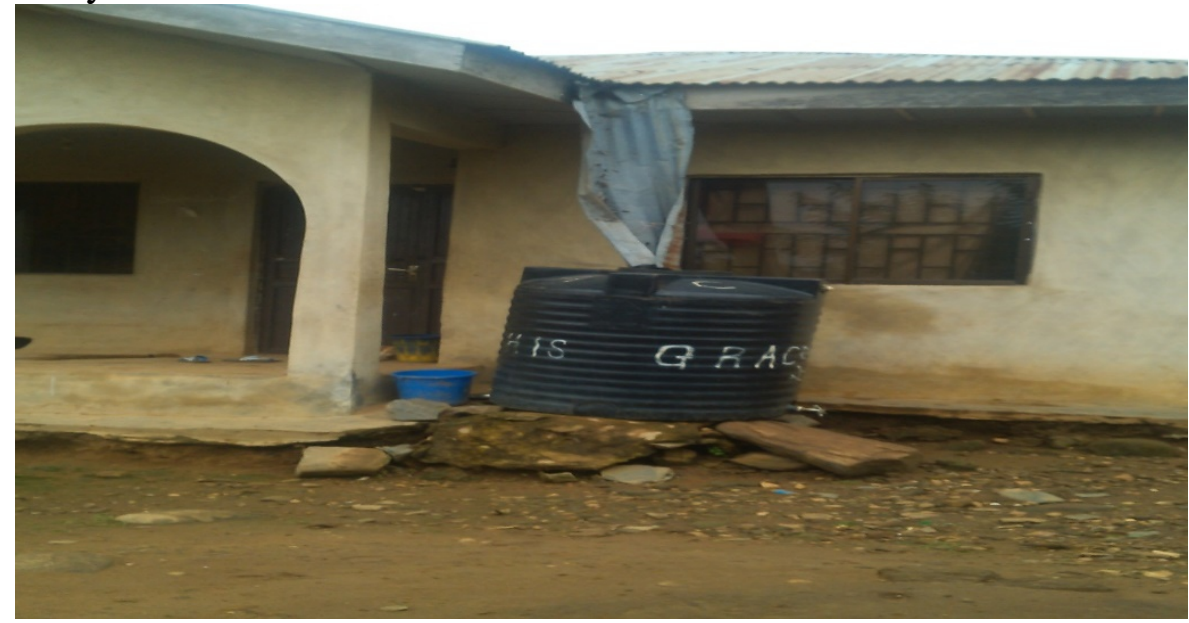

Plate 1: A typical rain water harvesting system in the study area.

All the collected samples were taken to the laboratory within two hours of collection and refrigerated at $4{ }^{\circ} \mathrm{C}$ in the laboratory till the analysis was carried out. Great care was taken to ensure the integrity of the samples. Various physio-chemical and bacteriological analysis were carried out on the water samples as described in APHA (2005).

\section{Results and discussion}

The results revealed that most of the samples had high concentrations of the physico-chemical and bacteriological parameters analyzed; often above the guideline values sourced from the WHO.

\section{Temperature}

The temperature of any water body affects the rate of proliferation of microorganisms (Pelczar et al., 2005). The temperature range of the samples rain water was 25.2 to $28.6{ }^{\circ} \mathrm{C}$ while the temperature of the well water sample was $27.8^{\circ} \mathrm{C}$. Figure 1 shows the temperature of the sampled waters. Although the temperature fell within WHO permissible limit of 23 to $40{ }^{\circ} \mathrm{C}$, the temperature recorded could be said to be suitable for the growth of heterotrophic bacterial species when present in the sample. It is also well 
known that temperature and ionic compositions of water significantly affects the electrical conductivity of water.

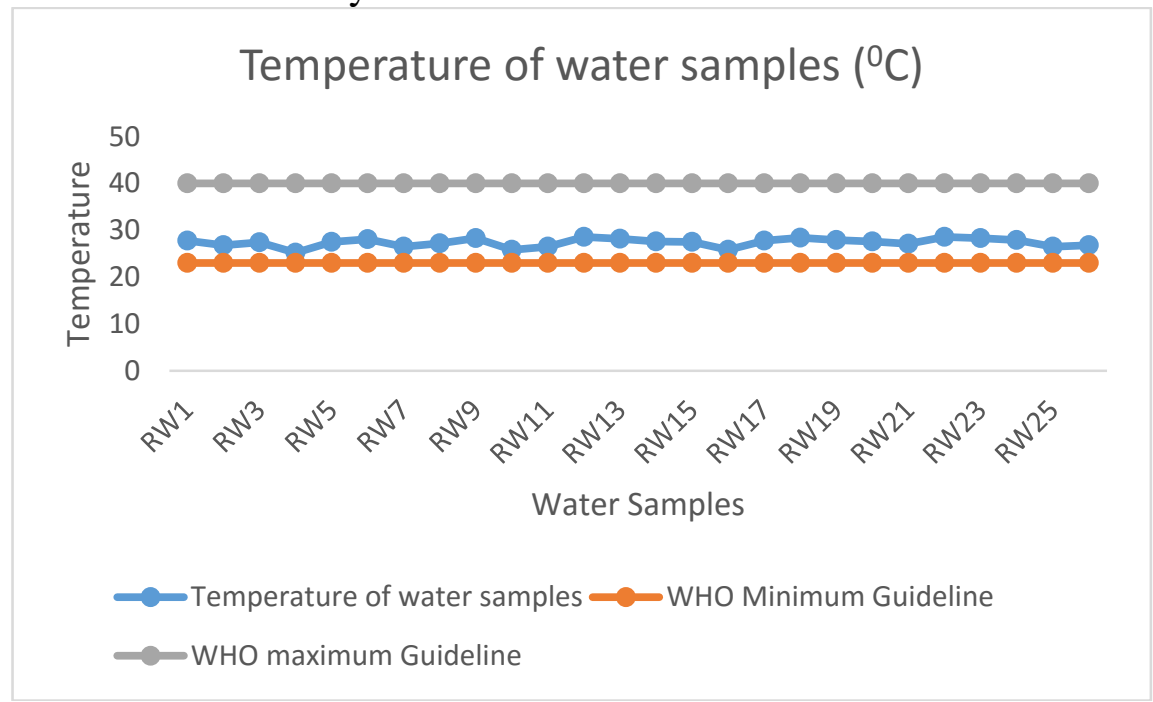

Figure 1: $\quad$ Temperature of water samples

\section{Turbidity}

The turbidity values ranged from 2.7 to 9.1 NTU for the harvested rainwater samples while the well water sample had a turbidity of 2.3 NTU. Approximately $90 \%$ of all the harvested rainwater samples collected in this study had turbidity values above WHO threshold. Turbidity of water is caused mainly by the presence of suspended matter, such as clay, silt, colloidal organic particles, plankton and other microscopic organisms that obstruct light transmission through water bodies (WHO, 2011). These colloidal materials provide adsorption sites for chemicals that may be harmful to health or cause undesirable tastes or odours (Adekunle et al., 2007). Increased levels of turbidity can impart an aesthetically displeasing appearance to water, and the materials that cause turbidity can provide adsorption sites for many contaminants. The materials can also allow adsorption of microorganisms, which protect the water from the effects of disinfection and can stimulate bacterial growth (WHO, 2004). In recognition of these factors and consumer acceptability, the WHO suggested that turbidity of potable water supplies should be at least less than five NTU. Figure 2 shows a graphical representation of the turbidity of the water samples. 


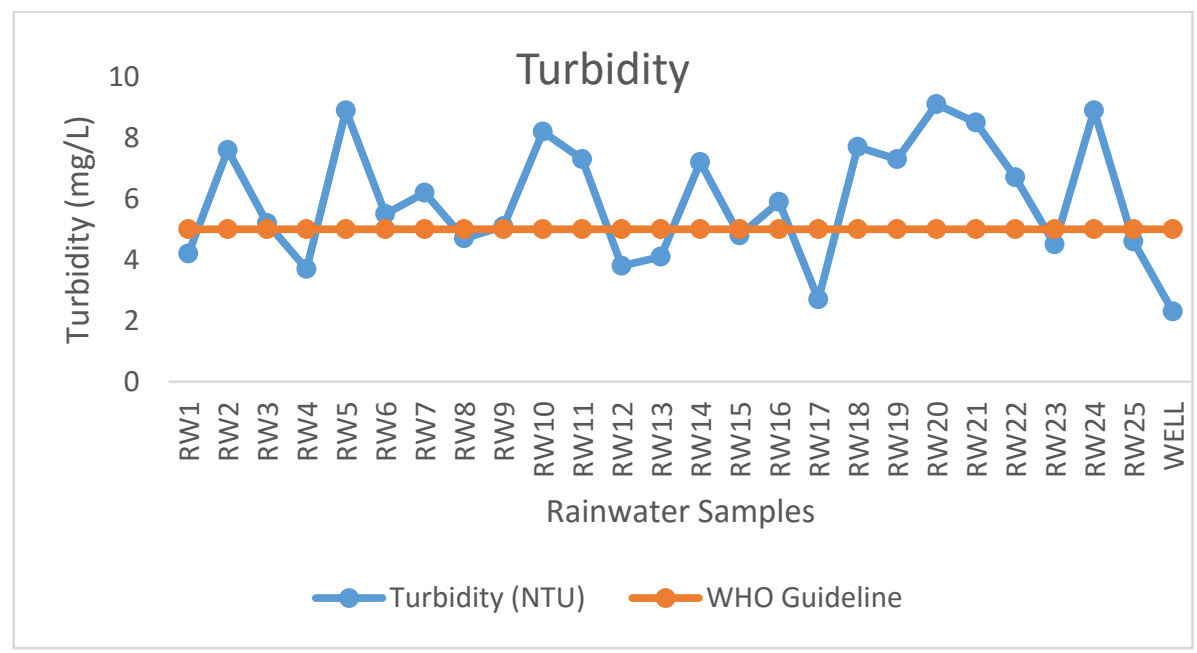

Figure 2: Turbidity of water samples

\section{Conductivity}

Conductivity indicates the presence of dissolved solids and contaminants especially electrolytes confirmed by the presence of cations in water. The conductivity values for the rainwater samples ranged from 101 to $1328 \mathbf{\Omega s} / \mathbf{c m}$. Figure 3 shows the conductivity values of the sampled water. The conductivity value was lower in the well water $(164 \mathbf{\Omega s} / \mathbf{c m})$ than in most of the harvested rain water samples which suggests that the mobility of dissolved ions is more in rain waters than in the well water. $40 \%$ of the harvested rainwater samples exceeded the WHO limit of $1000 \mathbf{\Omega s} / \mathbf{c m}$. This variation could not be accounted for but other physical properties of the waters which were not studied such as viscosity may be responsible. This assertion is not with certainty until further studies are carried out.

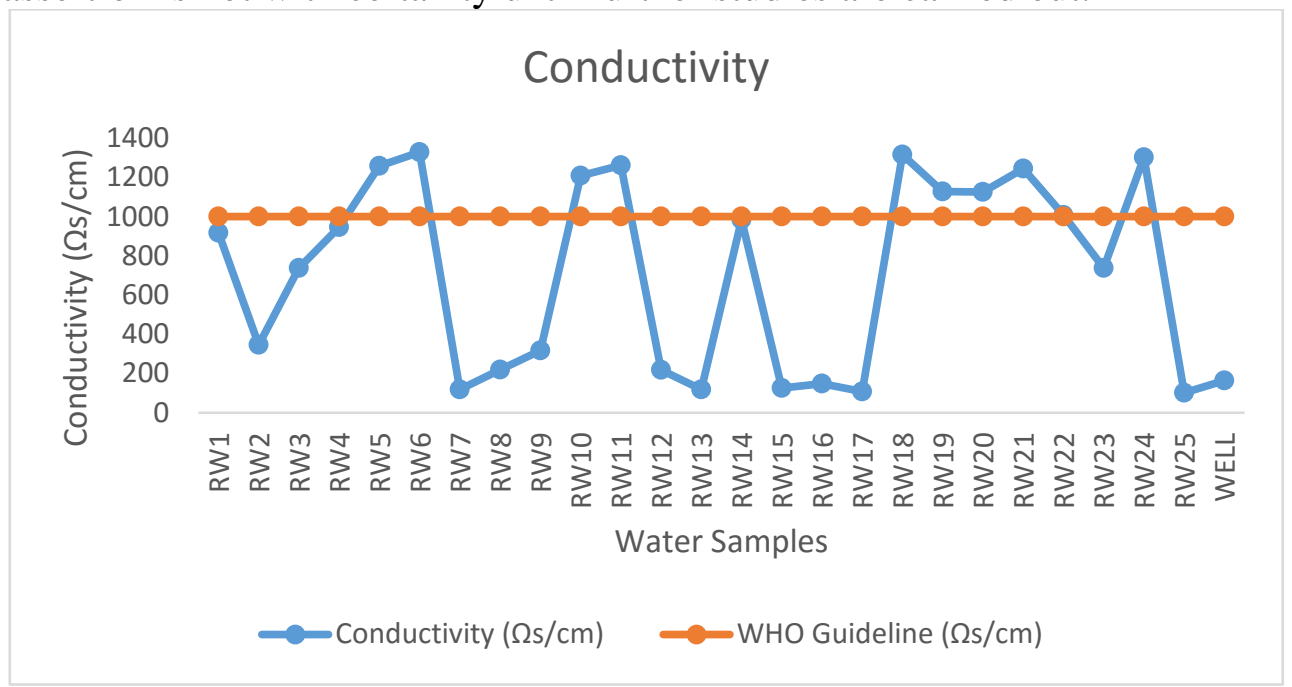

Figure 3: Conductivity of water sample $\mathrm{pH}$ 
The $\mathrm{pH}$ of the harvested rainwater ranged from 6.1 to 7.4 with $36 \%$ of the water samples having a $\mathrm{pH}$ of less than the WHO minimum limit of 6.5. The $\mathrm{pH}$ of the well water sample was 7.4 and was within the WHO acceptable limits of 6.5 to $8.5 . \mathrm{pH}$ is regarded as one of the most important indices of water quality because it influences chemical transformations and biological activities in the water. Absolutely neutral precipitation would have a $\mathrm{pH}$ of 7. However presumed that pure water is in equilibrium with global atmospheric $\mathrm{CO}_{2}$ and yield the natural acidity to the rain water with $\mathrm{pH}$ 5.6. This $\mathrm{pH}$ value 5.6 has been taken as the demarcation line for acidic precipitation. The lower mean $p \mathrm{H}$ values can be attributed to wet atmospheric deposition of $\mathrm{CO}_{2}, \mathrm{SO}_{2}$ and $\mathrm{NO}_{2}$ produced by vehicular emissions including the slash and burn method of land preparation for farming in the study communities. Kohler et al. (1997) in their study of the contribution of aircraft emission to atmospheric nitrogen content indicates that rainwater acquires slight acidity as it dissolves $\mathrm{CO}_{2}$ and $\mathrm{NO}_{2}$ gases in the atmosphere. On its own, however, $\mathrm{pH}$ has no direct effect on human or animal health, but because it is so closely associated with other chemical constituents of water, it is often regarded as having an indirect effect on health (WHO, 2011). It is evident that many chemical parameters generating extreme values of $\mathrm{pH}$ (i.e. either strong acids or bases) would impact frequently on human health (Ma et al., 2005). Figure 4 shows a graphical representation of the $\mathrm{pH}$.

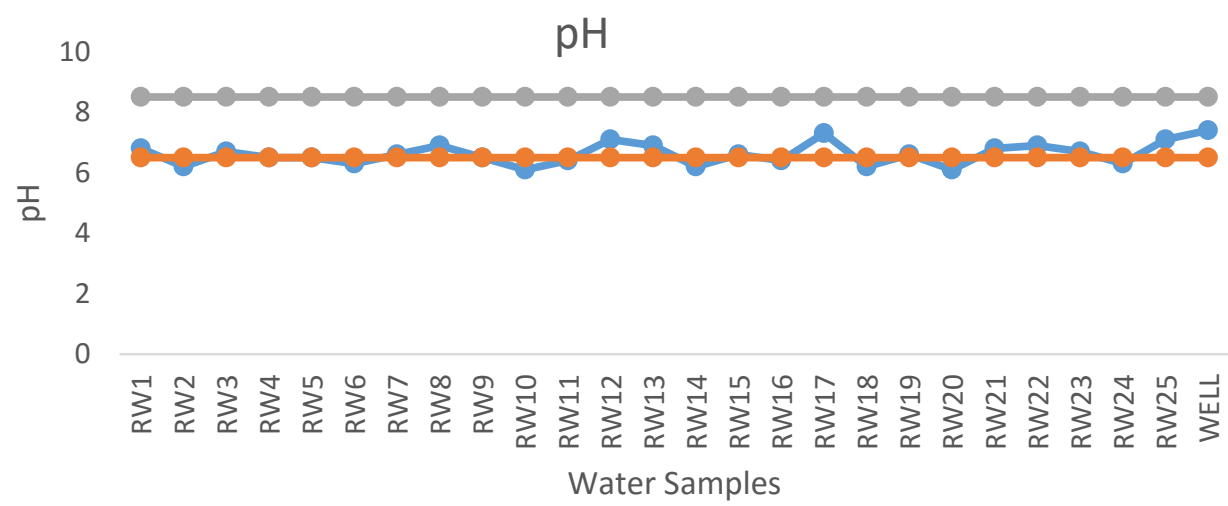

-pH@20oC —WHO Minimum Guideline - - WHO Maximum Guideline

Figure 4: pH of water samples.

\section{Total Dissolved Solids}

The values for total dissolved solids ranged from 152 to $1689 \mathrm{mg} / \mathrm{L}$ for the harvested rainwater samples with $68 \%$ of the rainwater samples exceeding the WHO limit of $500 \mathrm{mg} / \mathrm{L}$. The dissolved solids in the well 
water fell within WHO limit with a value of $326 \mathrm{mg} / \mathrm{L}$. Figure 5 shows the dissolved solids of the water samples.

\section{Total Dissolved Solids (mg/L)}

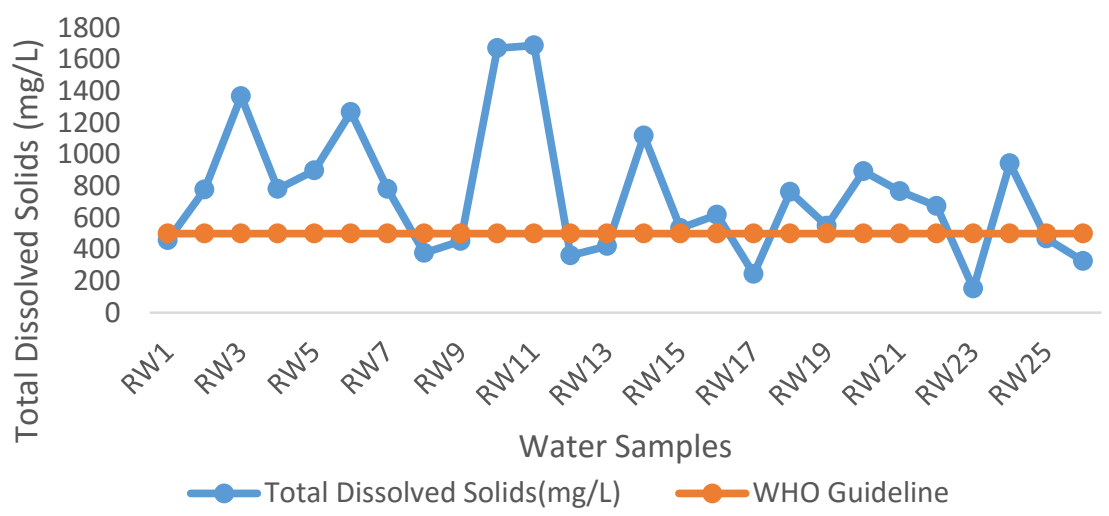

Figure 5: Dissolved Solids of Water Samples

\section{Total hardness of water samples}

The rainwater samples had a total hardness range of 152 to 1868 $\mathrm{mg} / \mathrm{L}$ while the total hardness of the well water sample was $264 \mathrm{mg} / \mathrm{L}$. The results also show that $84 \%$ of the rainwater samples had $\mathrm{pH}$ that exceeded the WHO limit of $500 \mathrm{mg} / \mathrm{L}$. According to WHO (2006) domestic water with total hardness above $500 \mathrm{mg} / \mathrm{L}$ is not recommended due to potential scale formation. According to Krishna (2003), Zero hardness of rainwater helps prevent scale formation on appliances. However, there is some indication that very soft water may have adverse effect on mineral balance (Appiah, 2008). Figure 6 shows a graphical illustration of the Total hardness of the water samples. 


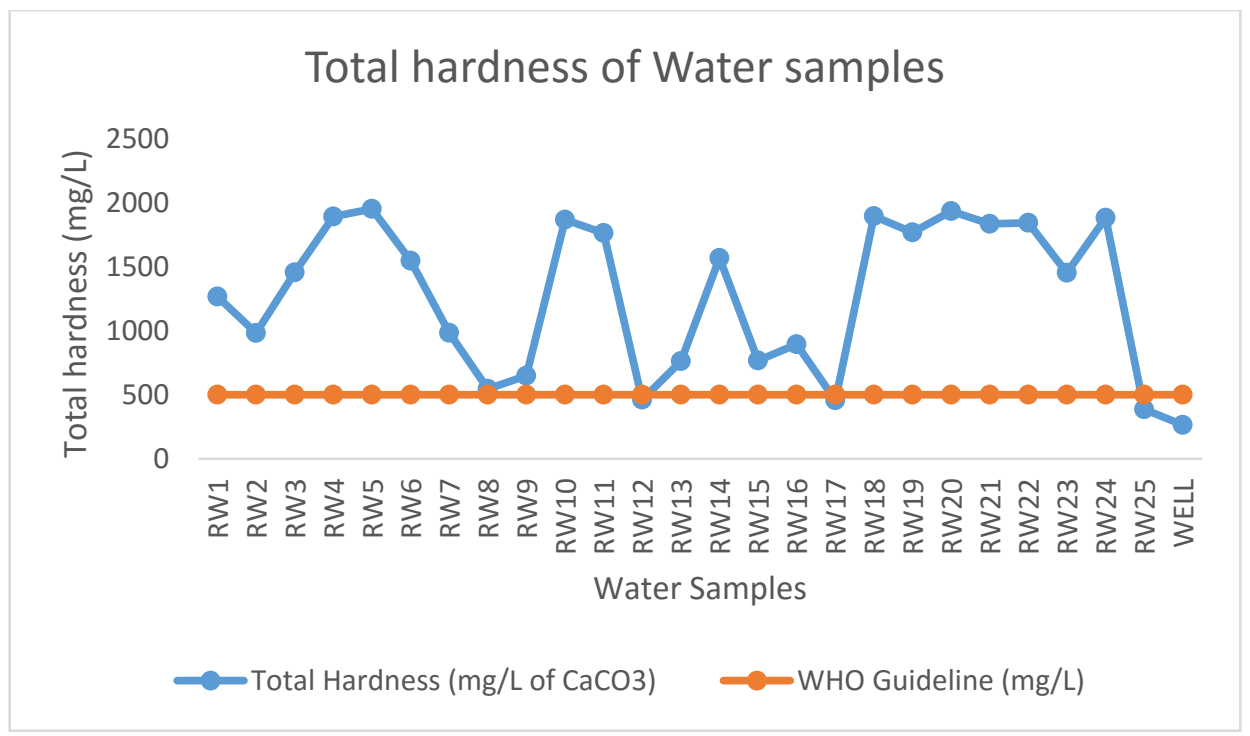

Figure 6: Total Hardness of water samples

\section{Nitrate}

The nitrate values for the harvested rain water ranged from 0.08 to $0.45 \mathrm{mg} / \mathrm{L}$. While the well water had nitrate value of $0.26 \mathrm{mg} / \mathrm{L}$. All the sampled water had nitrate values that fell within WHO acceptable limits of $50 \mathrm{mg} / \mathrm{L}$. High concentration of nitrate above $50 \mathrm{mg} / \mathrm{L}$ in drinking water is deleterious especially to babies due to the formation of methmoglobinamea (WHO, 2006). Figure 7 shows the nitrate values of the sampled waters. The presence of nitrates in a water sample could be due to inorganic fertilizers, plants and animal decomposition and wastes which may have percolated the soils over time (Ademoroti, 1995).

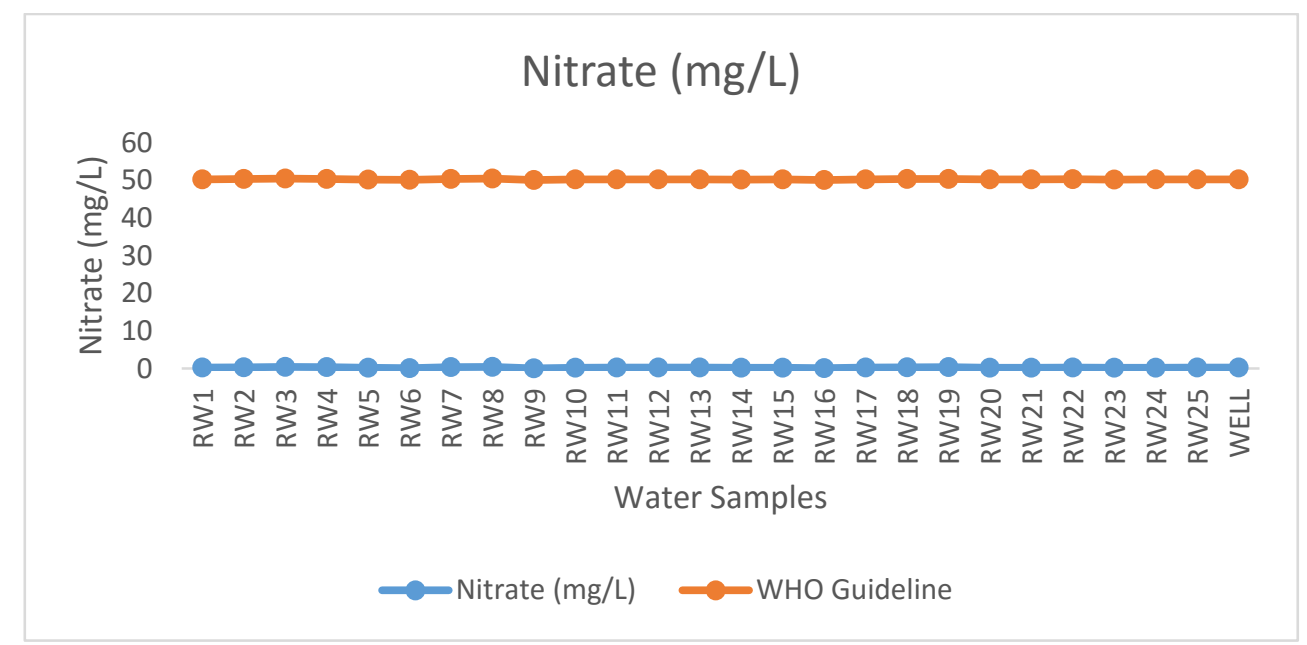

Figure 7: $\quad$ Nitrate values of water samples 


\section{Chloride}

The chloride values of the rain water water samples ranged from 3.5 to $48.2 \mathrm{mg} / \mathrm{L}$ while the well water had a $\mathrm{pH}$ of $2.8 \mathrm{mg} / \mathrm{L}$. The chloride values obtained fell within WHO maximum permissible limit of $250 \mathrm{mg} / \mathrm{L}$. Figure 8 shows the chloride values of the water samples. The salty taste of some water is due to the presence of chlorides in the form of sodium chloride, exceeding $250 \mathrm{mg} / \mathrm{L}$ of chlorides.

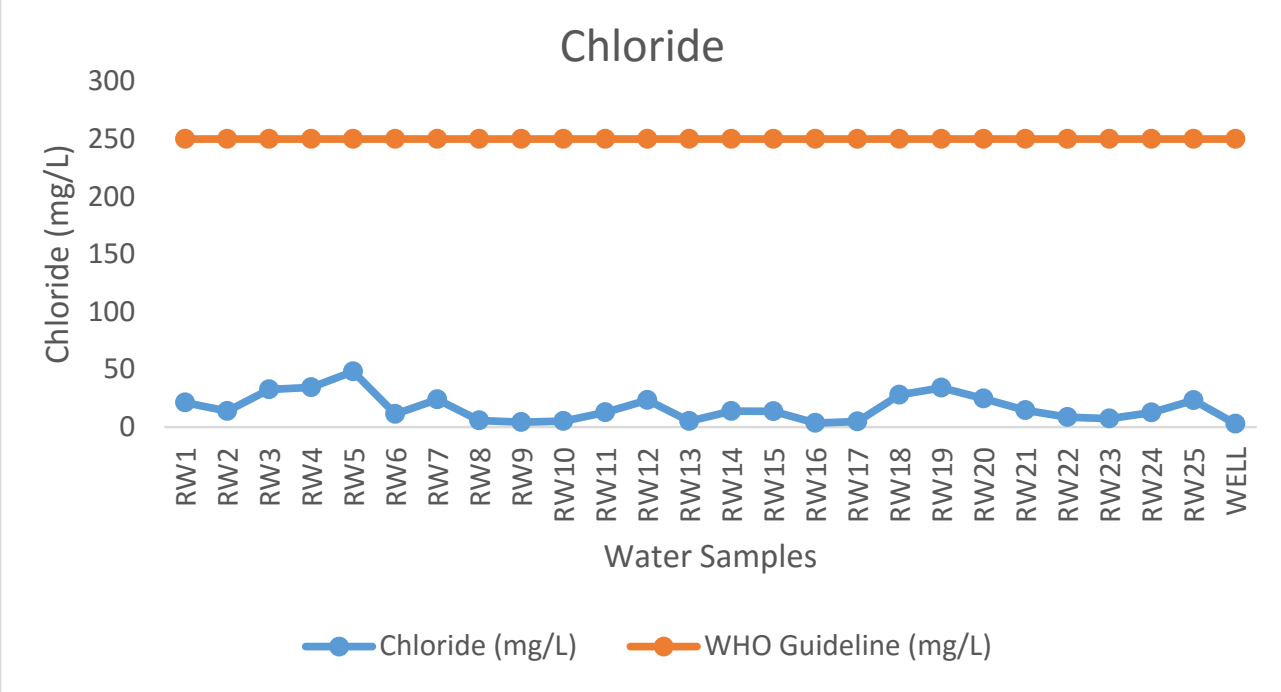

Figure 8: Chloride of water samples.

\section{Bacteriological Content of water samples}

All the sampled rainwaters and well water had total bacterial and coliforms and which were probably from the environmental sources and were most likely introduced into the water through the collection and storage process. However the bacterial present were mostly non-faecal in origin. The total bacterial content of the rain water samples ranged from 05 to 28 CFU/100mLwhile that of the well was 05 CFU/100mL. The total coliform contents of the rainwater samples ranged from 03 to $18 \mathrm{CFU} / 100 \mathrm{~mL}$, while that of the well was $02 \mathrm{CFU} / 100 \mathrm{~mL}$. WHO (2011) specified that potable drinking water should be devoid of total coliform in any given sample. Rainwater samples with high bacterial count also had high total coliform count and e-coli count. The Escherichia coli count of the rainwater samples ranged from zero to $11 \mathrm{CFU} / 100 \mathrm{~mL}$, while $28 \%$ of the rainwater samples had zero $e$-coli count. The well water had no e-coli present. Results of the bacteriological analysis obtained in this study is similar to that of Rogbesan et al. (2002) who also obtained bacterial content outside the range allowed by WHO. Figure 9 shows a graphical illustration of the results obtained from the bacteriological analysis. 


\section{Bacteriological Content}

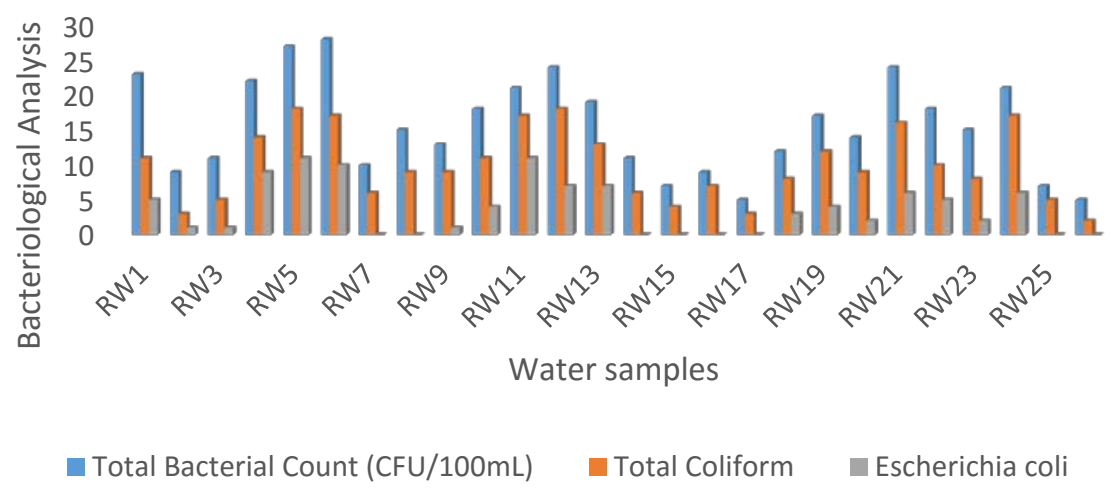

Figure 9: Bacteriological content of water samples.CONCLUSION

This study revealed that all the sampled rainwaters and well water had physio-chemical and bacteriological contamination, which were introduced into the water through the collection and storage process. This implies that all the rainwater samples are not fit for human consumption without appropriate treatment. The rainwater harvesting system should be clean and hygienic in order to promote safety of the water. Generally, the results of this study are indicative of high pollution of the water samples and require caution in the use of the water. Regular tests should be carried out on rainwater samples in order to ascertain its suitability for potable use. Based on the result of the analysis, it is recommended that harvested rainwater be adequately treated to disinfect contaminating microorganisms and to reduce the health risks associated with its consumption.

\section{References:}

Adekunle, I. M., Adekunle, M. T., Gbadebo, A. M. \& Banjoko, O. B. (2007). Assessment of Ground water Quality in a Typical Rural Settlement in Southwest Nigeria. Int. J. $\quad$ Environ.Res. Public Health., 4(4): 307 - 318

Ademoroti, C. M. A. (1995). Environmental Chemistry and Toxicology.Foludex Press Ltd.Ibadan

American Public Health Association (APHA) (2005). Standard Methods for the Examination of Water and Wastewater. 20th Edn., American Public Health Association, Washington D.C., U.S.A.

Arbués, F., Garcı-Valiñas, M.Á. \& Martınez-Espiñeira, R. (2003) Estimation of residential water demand: a state-of-the-art review. Journal of Socio-Economics, 32: 81102. 
Edema, M. O., Omemu, A. M. \& Fapetu, O. M. (2001). Microbiology and Physiochemical Analysis of different sources of drinking water in Abeokuta. Nigeria. Nigerian Journal of

Microbiology, 15(1): 57-61.

Hughes, J. M. \& Koplan, J. P. (2005). Saving Lives through Global Safe Water. Journal of Emerging Infectious Diseases. 11(10): 1636-1637.

Kohler, I., Sausen, R. \& Reinberger, R. (1997). Contribution of aircraft emission to the atmospheric NOx content. Atmos. Environ., 31: 18101818.

Kosek, M., Bern, C. \& Guerrant, R. L. (2003). The global burden of diarrhoeal disease, as estimated from studies published between 1992 and 2000. Bulletin of World Health

Organization, 81: 197-204.

Ma, J.Z., Wang, X.S. \& Edmunds, W.M. (2005). The characteristics of groundwater resources and their changes under the impacts of human activity in the arid North-West China - a case study of the Shiyang river basin. Journal of Arid Environments, 61: 277-295

Okonko, I. O., Ogunjobi, A. A., Adejoye, A. D., Ogunnusi, T. A. \& Olasogba, M. C. (2008). Comparative studies and microbial risk assessment of different water samples used for processing frozen sea foods in Ijora-olopa,Lagos State,Nigeria. African Journal of Biotechnology, 7 (16):2902-2907.

Parashar, U., Bresee, J. S. \& Glass, R. I. (2003). The global burden of diarrhoeal disease in children. Bulletin World Health Organization, 81: 236. Pelczar, M. J., Chan, E. C. S. \& Noel R. K.( 2005 ): Microbiology. 5th Edition, Tata Mc Graw Hill, New delhi. Pp. 571.

Rogbesan, A. A., Eniola., K. I. T. \& Olayemi, A. B. (2002). Bacteriological Examination of some Boreholes within University of Ilorin. Nigerian Journal of Pure and Applied Science, 117 - 223.

Umeh, C. N., Okorie, O. I. \& Emesiani, G. A. (2005). Towards the provision of safe drinking water: The bacteriological quality and safety of sachet water in Awka, Anambra State. In: the Book of Abstract of the 29th Annual Conference \& General Meeting on Microbes As Agents of Sustainable Development, organized by Nigerian Society for Microbiology (NSM), University of Agriculture, Abeokuta, pp. 22.

UNEP (United Nations Environment Programme), (2002). Global Environment Outlook (GEO- 3): 416.

World Health Organization (WHO (2004). Guidelines for drinking-water quality. 3rd ed. Volume 1: recommendations. Geneva: WHO. Available online at: (www.who.int/water_sanitation_health).

WHO (2005). The WHO Report 2005-make every mother and child count. Geneva. 
WHO (2006). Protecting Groundwater for Health: Managing the Quality of Drinking-water Sources. Edited by O. Schmoll, G. Howard, J. Chilton and I. Chorus. ISBN: 1843390795. Published by IWA Publishing, London, UK.

WHO (2011). Guidelines for drinking-water quality. 4th ed. WHO Press Geneva, Switzerland. 541p. Available at: www.who.int/water_sanitation_health/publications.

Zhu, Q. (2004). Quality issues in harvested rainwater in arid and semi- arid Loess Plateau of northern China, Journal of Arid Environment, 57: 487-505. 